\title{
Self-Perception Of Malocclusion And Barriers To Orthodontic Care: A Cross-Sectional Study In Al-Madinah, Saudi Arabia [Corrigendum]
}

\author{
Ashky RT, Althagafi NM, Alsaati BH, Alharbi RA, \\ Kassim SA, Alsharif AT. Patient Prefer Adherence.
} 2019;13:1723-1732.

The authors of this paper have advised that due to their error when submitting the manuscript, one of the authors names is spelt incorrectly.
The author name "Rawah Talal Ashky" should instead read "Rawah Talal Eshky" throughout the paper.

\section{Publish your work in this journal}

Patient Preference and Adherence is an international, peer-reviewed, open access journal that focusing on the growing importance of patient preference and adherence throughout the therapeutic continuum. Patient satisfaction, acceptability, quality of life, compliance, persistence and their role in developing new therapeutic modalities and compounds to optimize clinical outcomes for existing disease states are major areas of interest for the journal. This journal has been accepted for indexing on PubMed Central. The manuscript management system is completely online and includes a very quick and fair peer-review system, which is all easy to use. Visit http:// www.dovepress.com/testimonials.php to read real quotes from published authors. 